\title{
OPENING OF MICROCRACKS AND AIR PERMEABILITY IN CONCRETE
}

\author{
Michal STEHLÍK, Věra HEŘMÁNKOVÁ, Lubomír VÍTEK \\ Department of Building Testing, Faculty of Civil Engineering, \\ TU of Brno, Veveři 95, 60200 Brno, Czech Republic
}

Received 23 Apr 2012; accepted 11 Oct 2012

\begin{abstract}
The aim of this paper is to evaluate the suitability of the Torrent method of determining air permeability of concrete for an approximate assessment of damage to the surface layer of concrete caused by microcracks. The combined measurement of deformation and air permeability by means of Torrent method and of the width of microcracks on the tested concrete cubes during loading in the splitting tensile test contributed to the clarification of certain facts. The use of Torrent method seems to be more suitable in reinforced concretes where it is possible to anticipate a slower opening of cracks during the increase of load. In spite of that, the testing of these concretes is limited by the maximum dimensions of cracks, i.e. $0.075-0.1 \mathrm{~mm}$ in the width and $60 \mathrm{~mm}$ in the length. Exceeding these limit dimensions causes a massive decrease in vacuum and subsequent separation of the adhering bell of the Torrent tester.
\end{abstract}

Keywords: concrete, tensile splitting strength test, microcracks, air and water permeability, durability.

\section{Introduction}

The quality of construction work is nowadays assessed on the basis of three characteristics: load-bearing capacity, serviceability and useful life. An objective assessment of useful life, or durability, is based on a number of the so-called durability characteristics (Adámek et al. 2009; Matoušek, Drochytka 1998). They are determined by means of testing methods which examine the surface layer of concrete (cover concrete - "covercrete") with a thickness of 30-50 mm (Claisse et al. 1997; Wang, Hutchinson 2005; Kamaitis 2008). The permeability of concrete is directly dependent on the system of pores and cracks (Li et al. 2011) and it is influenced by many aspects - selection of materials, design of fresh concrete composition, its placement, compaction, and influence of an extreme load (Pavlík et al. 2007). Due to various influences, the cracks in concrete mutually interconnect and thus increase its resulting permeability (Aldea et al. 1999; Stehlík et al. 2005; Claisse et al. 2009; Akhavan et al. 2012).

The aim of this research is to test the applicability of the Torrent method of measuring air permeability of concrete surface layer for the determination of the degree of damage in the surface layer of concrete caused by microcracks (Romer 2005). Standard concrete cubes were subjected to the splitting tensile test (compressive force works diagonally on the cube) with a simultaneous monitoring of longitudinal and lateral deformations and air permeability (Berg, Rožkov 1968; Hoseini et al. 2009).
The direction of the present research was influenced to a large extent by the results of the work by a collective of authors in Stehlík et al. (2005). Here it was observed that the destruction (splitting) of the concrete cube occurs suddenly at the end of the tensile splitting strength test and it therefore does not allow for a continuous detailed measurement of the permeability coefficients $k_{T}$ in the range of 90 to $100 \%$ of the maximum load. However, according to Lim et al. (2000), microckracks begin to originate or open when the linear state of stress achieves $90 \%$ of the specimen's compressive strength, but according to Berg and Rožkov (1968), as early as at $15-45 \%$ the limit of origination of the first damage. In order to carry out a successful research into the dependence of permeability coefficient, load / total width of cracks, we proposed the reinforcement of concrete cube according to Reinhardt and Jooss (2003). This reinforcement was aimed to prolong, during the determination of splitting tensile strength, the time interval of the origination and opening of microcracks (up to the width of approx. $0.1 \mathrm{~mm}$ ) and thus to allow for a detailed measurement of permeability using the Torrent apparatus. The method of tensile loading of the cubes was selected on purpose because it enables the controlled origination and development of microcracks due to the induced tensile stress in concrete (Jokũbaitis 2007; Kaklauskas et al. 2012).

Similar issues have already been dealt with by several authors but nobody has so far made an attempt to use the Torrent method of determining air permeability

Corresponding author: Michal Stehlík

E-mail: stehlik.m@fce.vutbr.cz 


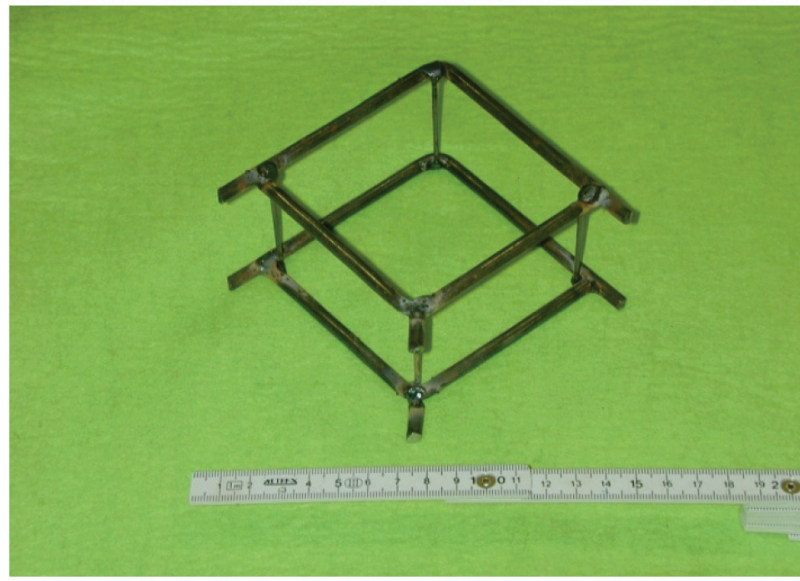

Fig. 1. Spatial arrangement of reinforcement

for the indication of damage to concrete caused by microcracks. For example Robins et al. (2001) studied the development of microckracks in the steel fibre reinforced concrete in bending, Aldea et al. (1999) studied the dependence between the cracking and permeability of concrete, Wang et al. (1997) generated cracks in concrete by means of feedback controlled splitting test and influenced thus its permeability. Yi et al. (2011) focused on the study of influence of the hydraulic pressure and width of microcracks on the permeability of concrete. Other authors evaluated the change in concrete permeability in relation to the width and coarseness of the crack surface (Akhavan et al. 2012), in relation to the change in the state of stress of concrete (Hoseini et al. 2009) and to the density and interconnection of cracks (Zhou et al. 2011).

\section{Materials and methods}

\subsection{Materials}

The reinforcement (Fig. 1) determined for the transfer of tensile strength in the concrete cube caused by splitting load was made of structural steel $10216 \varnothing 5.5 \mathrm{~mm}$. Two squares with the length of a side equal $90 \mathrm{~mm}$, bent from this round steel $\varnothing 5.5 \mathrm{~mm}$, were mutually stabilized by binding bars of $\varnothing 1 \mathrm{~mm}$ at a distance of $50 \mathrm{~mm}$. The reinforcement was moreover equipped with distance bars to maintain a constant distance from the shell of the mould during vibration (Fig. 2).

For the manufacture of test specimens, two formulations of a high-quality concrete for massive constructions were designed. Formulation A (Table 1) contains only the dense component of the coarse aggregate with fraction $4-8 \mathrm{~mm}$. The mixing of fine $(0-4 \mathrm{~mm})$ and coarse (4-8 $\mathrm{mm}$ ) fraction of natural dense aggregate was determined approximately by the ratio of 1:2. A highly effective plasticizer polycarboxylate, suitable for the manufacture of transport concrete and pumped concrete, was added in the volume of $1.1 \%$ of the cement mass per $1 \mathrm{~m}^{3}$ of concrete. Admixture of fly ash (from a power plant, ČR, spec. surface $240 \mathrm{~m}^{2} / \mathrm{kg}$ ) was dosed at the amount of $4.5 \%$ and microsilica (metallurgical flue dust,

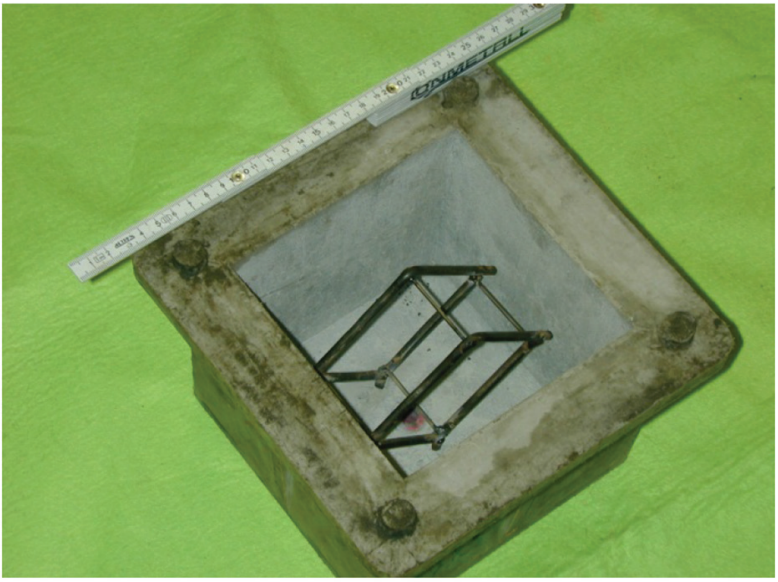

Fig. 2. Arrangement of reinforcement in polymer mould

Table 1. Formulation A

\begin{tabular}{lcc}
\hline $\begin{array}{l}\text { Formulation per } \\
1 \mathrm{~m}^{3}\end{array}$ & MU & Quantity \\
\hline $\begin{array}{l}\text { Natural dense agg. } \\
4-8 \mathrm{~mm}\end{array}$ & $\mathrm{~m}^{3}$ & 0.44 \\
& $\mathrm{~kg} / \mathrm{m}^{3}$ & $(1100 \mathrm{~kg})$ \\
$\begin{array}{l}\text { Natural dense agg. } \\
0-4 \mathrm{~mm}\end{array}$ & $\mathrm{~kg} / \mathrm{m}^{3}$ & 540 \\
\hline CEM I/42,5 R & $\mathrm{kg} / \mathrm{m}^{3}$ & 450 \\
\hline Fly ash & $\mathrm{kg} / \mathrm{m}^{3}$ & 20 \\
\hline Microsilica & $\mathrm{kg} / \mathrm{m}^{3}$ & 40 \\
\hline Polycarboxylate & 1 & 5 \\
\hline Water & - & 227.52 \\
\hline Water/cement ratio & & 0.41 \\
\hline
\end{tabular}

spec. surface $2350 \mathrm{~m}^{2} / \mathrm{kg}$ ) in the volume of $9 \%$ of the cement mass per $1 \mathrm{~m}^{3}$ of concrete (in Table 1 quantities of additives and admixtures are given in $\mathrm{kg}$ per $1 \mathrm{~m}^{3}$ of fresh concrete). These admixtures helped improve the hydration and physical-mechanical properties of fresh and hardened concrete. Slump class of the fresh concrete mixture prepared in a concrete mixer with forced mixing cycle was equal to $\mathrm{S} 3$ (slump 100-150 $\mathrm{mm}$ according to ČSN EN 4103). According to Formulation A, we made three test cubes $(150 \times 150 \times 150 \mathrm{~mm})$ of reinforced concrete (marked R-D, reinforced-dense concrete) with reinforcement according to Figure 2, and six test cubes of plain concrete (marked D, dense concrete). Formulation B (Table 2) contains, apart from dense coarse aggregate $4-8 \mathrm{~mm}$, also round lightweight silicate aggregate of fraction 4-8 $\mathrm{mm}$ from expanded clay (bulk weight $\left.350 \mathrm{~kg} / \mathrm{m}^{3}\right)$. The doses and properties of the remaining ingredients of concrete for Formulation B correspond to the above described Formulation A. According to Formulation $B$ we again made three test cubes of reinforced structural lightweight concrete (marked R-L, reinforcedlightweight concrete), and six test cubes of unreinforced 
structural lightweight concrete (marked L). The resulting strengths of both triplets of unreinforced concrete cubes after 28 days of moist curing are shown in Table 3.

Considering the large volume of measurements ( 9 concrete cubes) and considering the comparability of measured results, two pairs of cubes were chosen for the purpose of presenting the dependence between the permeability coefficient and load / total width of cracks. They were made from Formulation A - pair R1-D (reinforced concrete) and 3-D (plain concrete), and from Formulation B - pair R1-L (reinforced structural lightweight concrete) and 3-L (structural lightweight concrete).

\subsection{Methods}

The linear state of stress of the concrete cube with the dimensions of 150/150/150 $\mathrm{mm}$ was achieved by its diagonal loading between the compression plates of the hydraulic press in accordance with the recommendation of ČSN EN 12390-6 Testing hardened concrete Part 6: Splitting tensile strength of test specimens, see Figure 3.

The incipient longitudinal $\left(\varepsilon_{\text {lon }}\right)$ and transverse $\left(\varepsilon_{\text {trans }}\right)$ deformations of the cube were measured at each stage of loading by means of Hollan mechanical contact deformeter. This device is made of pairs of disks attached to the angular points of concrete cube faces (Fig. 3). The change in permeability in one face of the concrete cube was measured at the selected stages of loading by means of an apparatus for testing air permeability Torrent permeability tester (Fig. 4). We created vacuum on the concrete surface under the bell by means of the vacuum pump (Fig. 5) and measured the flow of air from the concrete cube to the measuring device over a time interval set in advance. The air current decreased the achieved value of the vacuum - see Fig. 4. The width of microcracks was identified and measured by means of the optical microscope with a maximum precision of $0.005 \mathrm{~mm}$ (Fig. 6).

Table 2. Formulation B

\begin{tabular}{lcc}
\hline Formulation per $1 \mathrm{~m}^{3}$ & MU & Quantity \\
\hline $\begin{array}{l}\text { Natural dense agg. } \\
4-8 \mathrm{~mm}\end{array}$ & $\mathrm{~m}^{3}$ & 0.11 \\
\cline { 3 - 3 } $\begin{array}{l}\text { Lightweight agg. } \\
\text { (expanded clay) } \\
4-8 \mathrm{~mm}\end{array}$ & $\mathrm{~m}^{3}$ & $(275 \mathrm{~kg})$ \\
\cline { 2 - 3 } $\begin{array}{l}\text { Natural dense agg. } \\
0-4 \mathrm{~mm}\end{array}$ & $\mathrm{~kg} / \mathrm{m}^{3}$ & 0.33 \\
\hline CEM I/42,5 R & $\mathrm{kg} / \mathrm{m}^{3}$ & 540 \\
\hline Fly ash & $\mathrm{kg} / \mathrm{m}^{3}$ & 450 \\
\hline Microsilica & $\mathrm{kg} / \mathrm{m}^{3}$ & 40 \\
\hline Polycarboxylate & $\mathrm{kg} / \mathrm{m}^{3}$ & 5 \\
\hline Water & 1 & 227.52 \\
\hline Water/cement ratio & - & 0.41 \\
\hline
\end{tabular}

The purposeful combination of cubes of the same formulation with and without reinforcement was aimed at confirmation of the positive influence of reinforcement on the deceleration of the opening of cracks during the splitting tensile test. Each individual cube was placed diagonally between the duralumin angle bars propped against the pressure plates of the hydraulic press (Fig. 4). At each stage of loading, deformations were read, and at the selected points we determined both the concrete permeability coefficient $\mathrm{k}_{\mathrm{T}}$ using the Torrent apparatus, and identified the origination, number and width of microcracks by means of the optical microscope. All the four cubes were loaded step by step from the lower limit corresponding to $1 / 10$ of the anticipated load bearing capacity. In the course of adding load, the previous load was always increased by $20 \mathrm{kN}$. After achieving $50-60 \%$ of load from the maximum, we carried out the cycling from the given loading stage to the lower limit up to the moment of falling off of the vacuum bell of the Torrent apparatus on one of the faces of the tested concrete cube (crack width $>0.05$ to $1.00 \mathrm{~mm}$ ). Then we continued the gradual regular adding of load up to the moment of the loss of the load-bearing capacity of the concrete cube.

\section{Results and discussion}

The following two figures (Figs 7 and 8) show the process of deformation of the four concrete cubes during the above described loading in the splitting tensile test. The deformation diagrams of the two cubes made from the same formulation are combined in such a way that the impact of reinforcement on the deformations in progress becomes apparent. The red (Fig. 7) and purple (Fig. 8) deformation curve represent the reinforced concrete cubes, the green and blue curves representing the cubes made of unreinforced concrete.

Both pairs of deformation diagrams of concrete cubes are very similar, therefore, the relative deformations of cubes made of unreinforced and reinforced concrete and those of cubes made of structural lightweight concrete with reinforcement and without it are not markedly different. However, the assessment of impact of the additional tension reinforcement is more complicated. The reinforcement decreases, up to approximately $70 \%$ of the maximum load, the values of both longitudinal

Table 3. Average strength of concrete specimens from Formulations A and B after 28 days in moist environment

\begin{tabular}{lccc}
\hline Formulation & $\begin{array}{c}\text { Splitting } \\
\text { tensile } \\
\text { strength }\end{array}$ & $\begin{array}{c}\text { Compressive } \\
\text { strength }\end{array}$ & $\begin{array}{c}28 \text { days } \\
\text { volume mass }\end{array}$ \\
\cline { 2 - 4 }$(\mathrm{MPa})$ & $(\mathrm{MPa})$ & $\left(\mathrm{kg} / \mathrm{m}^{3}\right)$ \\
\hline $\begin{array}{l}\text { A, specimens } \\
\text { B specim }\end{array}$ & 4.8 & 65.6 & 2233 \\
\hline \begin{tabular}{l} 
B specimens \\
\hline
\end{tabular} & 2.9 & 48.0 & 1800 \\
\hline
\end{tabular}




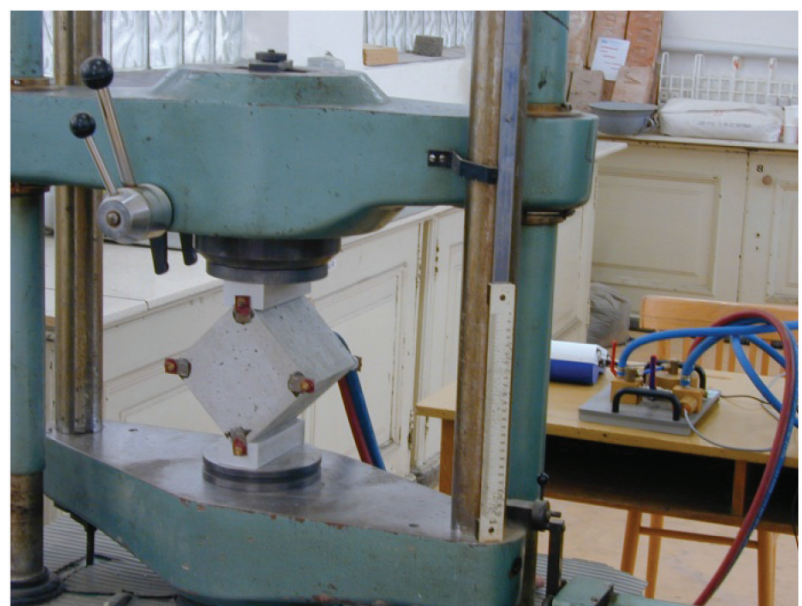

Fig. 3. Splitting tensile strength test in hydraulic press machine with a range of 40 tons

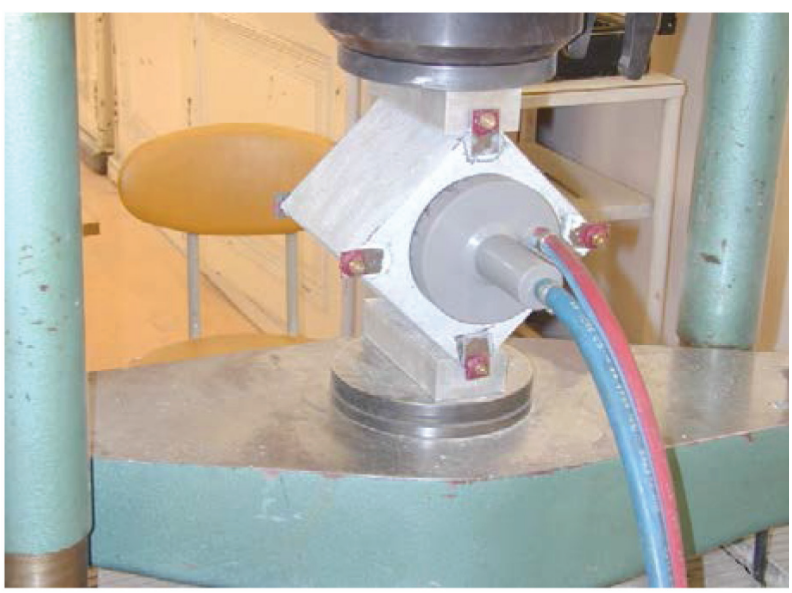

Fig. 5. Suction of air through cracked concrete with Torrent vacuum bell

and transverse deformation by $30 \%$. During further loading the cube suddenly breaks and the deformation values increase abruptly. But the broken cube has, due to the tension reinforcement, an approximately one third reserve to achieving the load-bearing capacity (see red and purple curve in Figs 7 and 8). In the case of loading the cubes of unreinforced concrete the moment of damage (breakage) occurs at the moment of achieving the load-bearing capacity (See green and blue curve in Figs 7 and 8). Figures 9 and 10 present the measured dependence of the permeability coefficient $\mathrm{k}_{\mathrm{T}}$ on the relative transverse deformation $\left(\varepsilon_{\text {trans }}\right)$. It is apparent from both pairs of graphs that at a load of over approx. 30\% of the estimated splitting tensile strength and at the corresponding relative deformation, the values of permeability coefficients in the reinforced cubes of both formulations are lower than those in the cubes without reinforcement. These results confirm the ability of the reinforcement to transmit part of the tensile strength in the concrete cube during the splitting tensile test and thus to decrease the total number and width of microcracks.

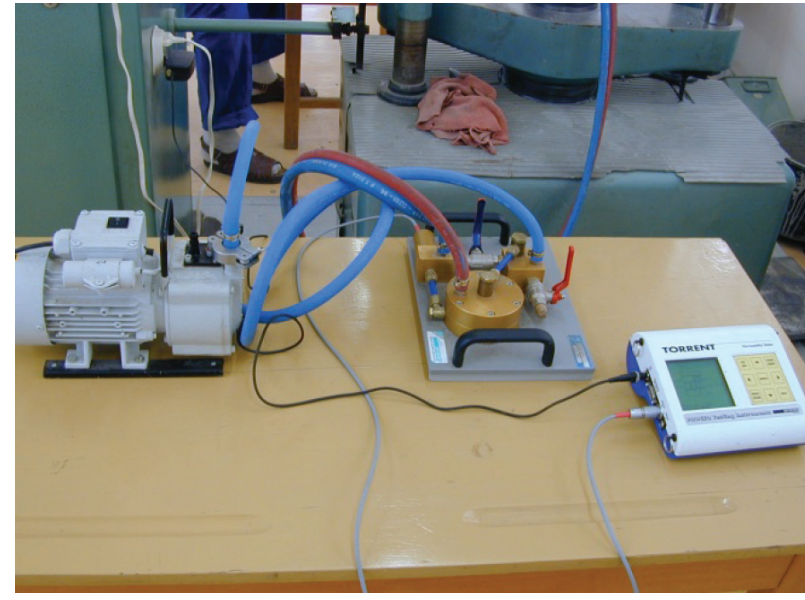

Fig. 4. Full set of Torrent permeability tester

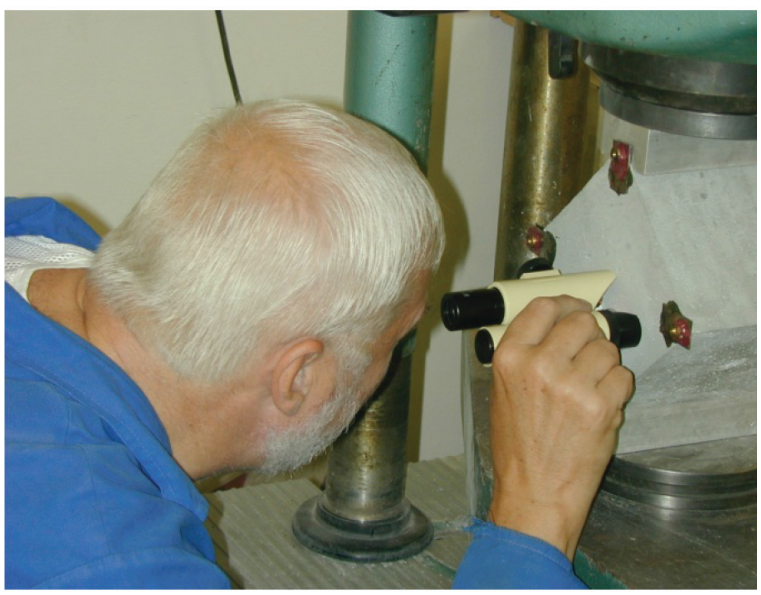

Fig. 6. Microcracks detection with optical microscope

The searched dependence of the permeability coefficient $k_{T}$ and the load on the total width of cracks is represented in Figure 11 for Formulation A and in Figure 12 for Formulation B. On the grounds of the objective assessment of the quantity and width of microcracks in the specimen of concrete under increasing load, the notion of "total width of cracks" was introduced as a plain sum of maximum widths of all cracks identified by both the microscope and the naked eye. From the comparison of corresponding dependencies in both formulations it is apparent that for future possible determination of correlation dependence of permeability coefficient / total width of cracks it is more suitable to test cubes reinforced with steel. In these the reinforcement slows down the opening of microcracks for a certain time interval (in the range of approx. $70-90 \%$ of the maximum load in the reinforced cubes) and thus prolongs the interval of measurability of concrete permeability using the Torrent apparatus. In both graphs (Figs 11 and 12) this different interval of measurability is represented by a different length of the red (purple) and green (blue) curve in the tested dependence 


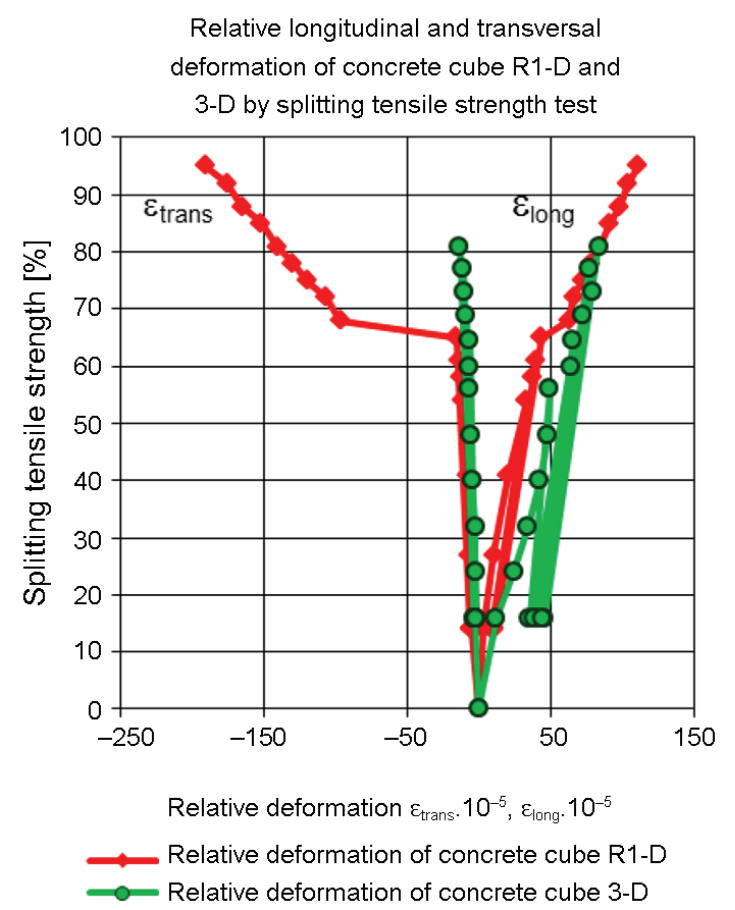

Fig. 7. Stress-strain diagram of concrete cube R1-D and 3-D under splitting tensile strength test

Change in coefficient of permeability $k_{T}$ of concrete cube R1-D (red curve) and 3-D (green curve) by splitting tensile strength test

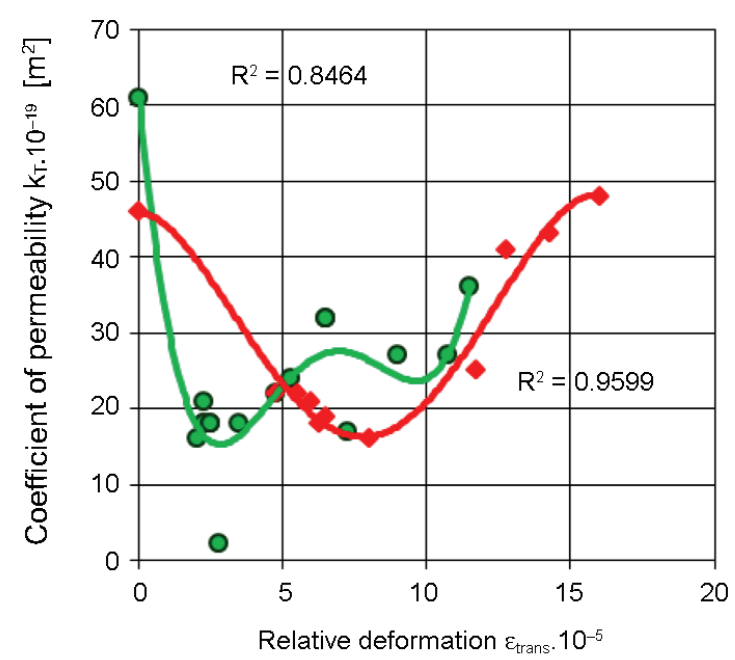

Fig. 9. Dependence of $\mathrm{k}_{\mathrm{T}} / \mathrm{l}_{\text {trans }}$ for concrete cube R1-D and 3-D

of the permeability coefficient / total width of cracks. It is also apparent that the cube made of structural lightweight concrete is more liable to deformation, the first cracks appearing at a $25 \%$ load of the maximum load, contrary to the $55 \%$ in the case of mass concrete made of dense aggregate. This also corresponds with the measured, approximately 5 -fold values of permeability coefficients $\mathrm{k}_{\mathrm{T}}$ in structural lightweight concretes (also reinforced) compared to the mass concrete and reinforced concrete.

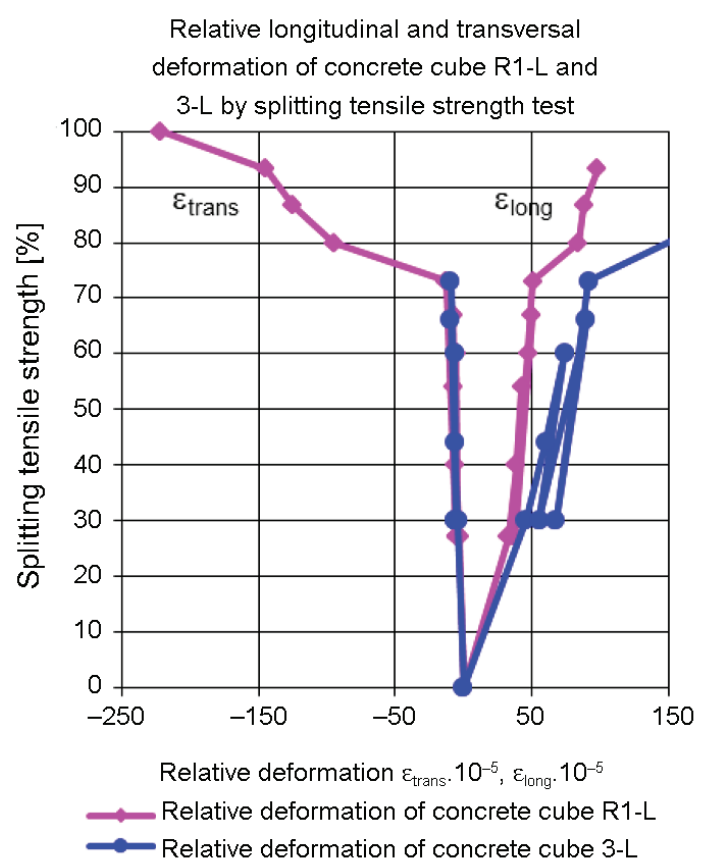

Fig. 8. Stress-strain diagram of concrete cube R1-L and 3-L under splitting tensile strength test

Change in coefficient of permeability $\mathbf{k}_{\top}$ of concrete cube R1-L (purle curve) and 3-L (blue curve) by splitting tensile strength test

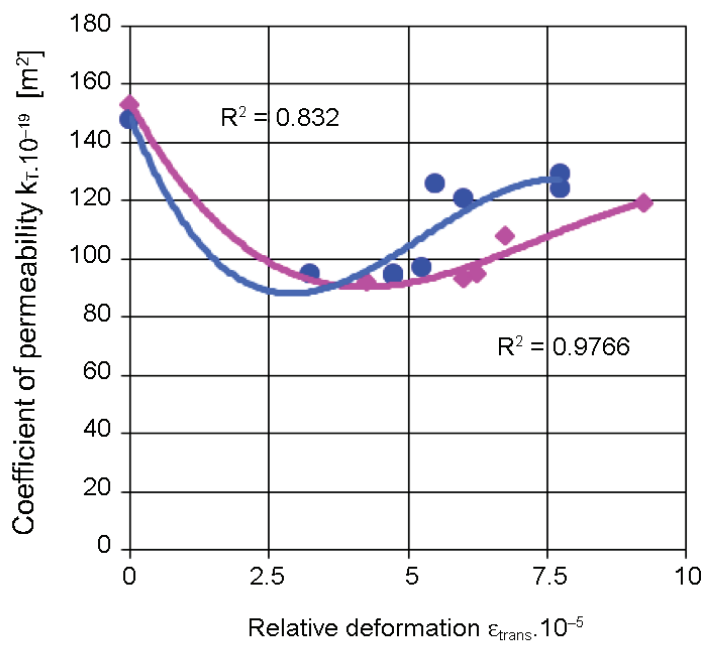

Fig. 10. Dependence of $\mathrm{k}_{\mathrm{T}} / \mathrm{l}_{\text {trans }}$ for concrete cube R1-L and $3-\mathrm{L}$

The comparison of graphs from Figures 11 and 12 brings one more interesting finding: the upper range of measurability of the permeability of unreinforced concrete using the Torrent method is limited by $85 \%$ of load in both formulations, in the reinforced concrete by $95 \%$ load of the maximum. However, it is necessary to note that tension reinforcement of the concrete cube increases the ultimate strength in the splitting tensile test by $1 / 3$, compared with the unreinforced concrete. 
Coefficient of permeability $k_{\top}$ and per cent of load from maximum depending on the total width of cracks in cube R1-D and 3-D
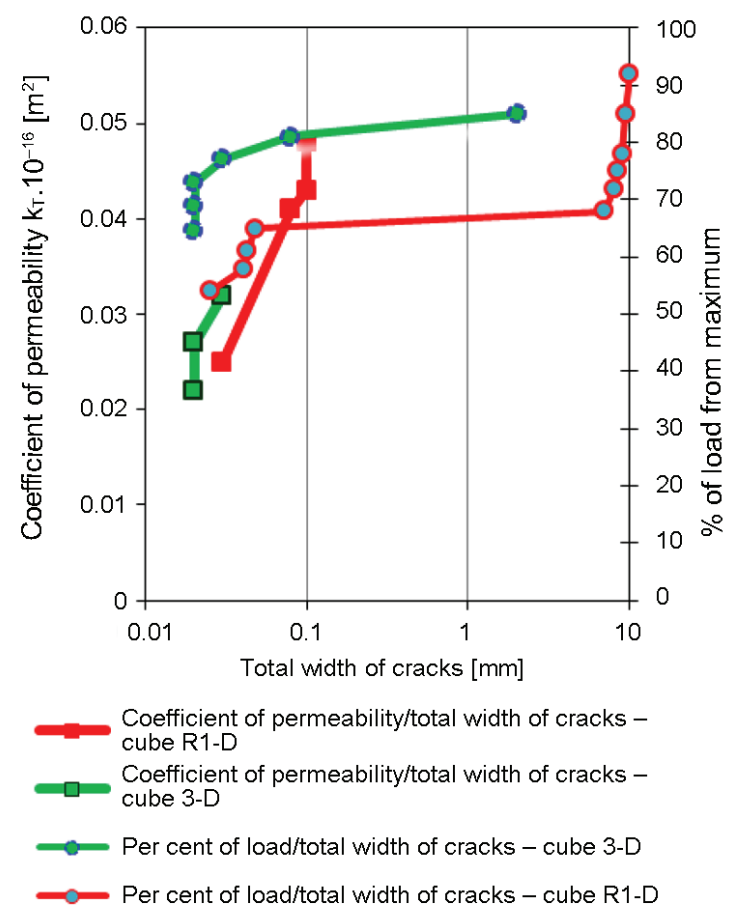

Fig. 11. Monitored dependencies on concrete cube R1-D and 3-D

By a combined measurement of deformation, permeability using the Torrent method and of the number and width of microcracks by microscope on the cubes during the selected stages of loading, the following facts were found out:

a) Tension reinforcement in the concrete cube does not prevent longitudinal splitting of the cube in the Grenoble test but increases the splitting tensile strength by approx. $1 / 3$;

b) Due to the above mentioned facts a) and b) the tension reinforcement increases the measurability range of the permeability coefficient $\mathrm{k}_{\mathrm{T}}$ of the concrete cube during the Grenoble test;

c) During the loading of cubes (both reinforced and unreinforced) up to approx. $30 \%$ of the maximum load it is possible to observe a decrease in the permeability coefficients $\mathrm{k}_{\mathrm{T}}$ caused by the initial compression of the specimens; during their further loading, the permeability coefficients $\mathrm{k}_{\mathrm{T}}$ are beginning to increase;

d) The moment of the beginning of increase in the coefficient $\mathrm{k}_{\mathrm{T}}$ coincides with the beginning of origination and development of microcracks, which corresponds to the load of approx. $25 \%$ of the maximum in the structural lightweight concrete (both reinforced and unreinforced) and to approx. 55\% of the maximum load in the plain and reinforced concrete;
Coefficient of permeability $\mathbf{k}_{\mathrm{T}}$ and per cent of load from maximum depending on the total width of cracks in cube R1-L and 3-L

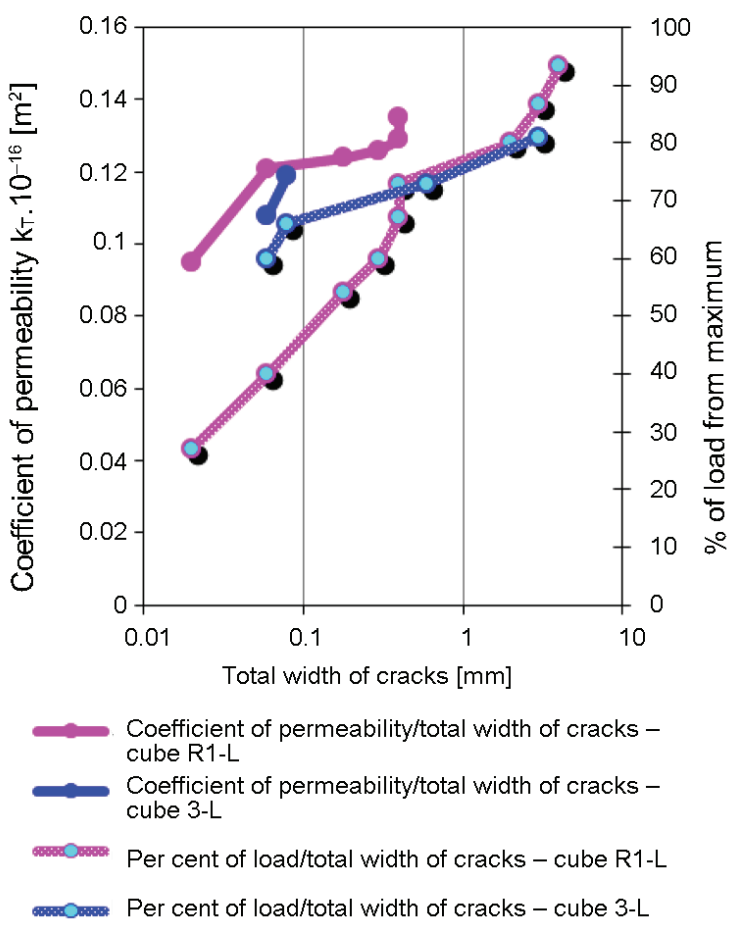

Fig. 12. Monitored dependencies on concrete cube R1-L and $3-\mathrm{L}$

e) The permeability coefficients $\mathrm{k}_{\mathrm{T}}$ of the cubes made of structural lightweight concrete (both reinforced and unreinforced) achieve values five times higher in comparison with those of the plain and reinforced concrete; deformation characteristics are, on the other hand, very similar;

f) By optical microscope it is possible to identify cracks with a minimum width of $0.005 \mathrm{~mm}$ theoretically. Cracks with a minimum width of $0.01 \mathrm{~mm}$ were identified practically in the tested cubes of the two formulations according to d);

g) The maximum width of a microcrack at which it is possible to determine the permeability coefficient $\mathrm{k}_{\mathrm{T}}$ using the Torrent method equals $0.075-0.1 \mathrm{~mm}$. In case of a greater width of the microcrack, its length usually exceeds the limit value of $60 \mathrm{~mm}$. This value is given by an interior diameter of the vacuum bell of the Torrent tester and if it is exceeded, the vacuum inside the bell sticking to the cube decreases and the bell falls off due to gravitation.

\section{Conclusions}

The non-destructive Torrent method for determining the air permeability coefficient of the surface layer of concrete (30-50 $\mathrm{mm}$ in depth), can be successfully used also for the evaluation of damage to concrete caused by 
microcracks. The obtained research results confirm the possibility of using the Torrent method, however, with a number of instrument limitations as well as physicalmechanical limitations. The limiting dimensions (width, length) of the originating microcracks seem to be the most important limitation. If these are exceeded, the vacuum in the Torrent tester bell is threatened by a strong stream of external air through the crack. The extent of measurability of the permeability coefficient is, on the contrary, substantially increased by tension reinforcement which decreases both longitudinal and lateral deformation of the concrete cubes by up to $1 / 3$. This decrease in deformations finally contributes to limiting the origination and opening of microcracks. A rough determination of the extent of damage by means of Torrent tester can be favourably done from the correlation dependence in Figures 11 and 12 permeability coefficient $/$ total width of cracks (or possibly a degree of surface damage to concrete) for ordinary and lightweight concrete. The $\mathrm{x}$ axis, however, does not define the width and length of cracks but the technologically more advantageous (fast progression of measurement, exclusive use of optical microscope) total width of cracks. The width is limited by $7 \mathrm{~mm}$ in case of structural lightweight concrete, and $10 \mathrm{~mm}$ in case of unreinforced concrete. In order to determine a more precise correlation dependence of permeability coefficient / total width of cracks it would be necessary to extend the spectrum of tested concretes.

\section{Acknowledgements}

The authors wish to thank for the support of VVZ MSM 0021630511 "Progressive Building Materials with Utilization of Secondary Raw Materials and Their Impact on Structures Durability" and GA ČR 13-18870S “Assessment and Prediction of the Concrete Cover Layers Durability".

\section{References}

Adámek, J.; Juránková, V.; Stehlík, M. 2009. Alternative point of view on concrete durability, in $12^{\text {th }}$ International Scientific Conference "Natural and Social Science": Selected papers, April 2009, Vol. 1: 5-8.

Akhavan, A.; Shofaatian, S. M. H.; Rajabipour, F. 2012. Quantifying the effects of crack width, tortuosity and roughness on water permeability of cracked mortars, Cement and Concrete Research 42(2): 313-320. http://dx.doi.org/10.1016/j.cemconres.2011.10.002

Aldea, C. M.; Shah, S. P.; Karr, A. 1999. Permeability of cracked concrete, Materials and Structures 32(5): 370-376. http://dx.doi.org/10.1007/BF02479629

Berg, O. J.; Rožkov, A. J. 1968. Vlijanije izmenenija struktury betona na jego pročnost' i deformativnije svojstva [Influence of the change in concrete structure on its strength and deformation properties]. Report of the solution of RVHP task. Dresden.

Claisse, P. A.; Elsayad, H. I.; Ganjian, E. 2009. Water vapour and liquid permeability measurements in cementitious samples, Advances in Cement Research 21(2): 83-89. http://dx.doi.org/10.1680/adcr.8.00046
Claisse, P. A.; Elsayd, H. I.; Shaaban, I. G. 1997. Absorption and sorptivity of cover concrete, Journal of Materials in Civil Engineering 9(3): 105-110. http://dx.doi.org/10.1061/(ASCE)0899-1561(1997)9:3(105)

Hoseini, M.; Bindiganavile, V.; Banthia, N. 2009. The effect of mechanical stress on permeability of concrete: a review, Cement and Concrete Composites 31(4): 213-220. http://dx.doi.org/10.1016/j.cemconcomp.2009.02.003

Jokūbaitis, V. 2007. Regularities in propagation of opened corrosion-induced cracks in concrete, Journal of Civil Engineering and Management 13(2): 107-113.

Kaklauskas, G.; Gribniak, V.; Jakubovskis, R.; Gudonis, E.; Salys, D.; Kupliauskas, R. 2012. Serviceability analysis of flexular reinforced concrete members, Journal of Civil Engineering and Management 18(1): 24-29. http://dx.doi.org/10.3846/13923730.2011.643553

Kamaitis, Z. 2008. Modelling of corrosion protection for reinforced concrete structures with surface coatings, Journal of Civil Engineering and Management 14(4): 241-249. http://dx.doi.org/10.3846/1392-3730.2008.14.23

Li, K.; Ma, M.; Wang, X. 2011. Experimental study of water flow behaviour in narrow fractures of cementitious materials, Cement and Concrete Composites 33(10): 1009-1013. http://dx.doi.org/10.1016/j.cemconcomp.2011.08.005

Lim, C. C.; Gowripalan, N.; Sirivivatnanon, V. 2000. Microcracking and chloride permeability of concrete under uniaxial compression, Cement and Concrete Composites 22(5): 353-360. http://dx.doi.org/10.1016/S0958-9465(00)00029-9

Matoušek, M.; Drochytka, R. 1998. Atmosférická koroze betonu [Atmospheric corrosion of concrete]. Praha: IKAS+ ̌́KAIT, 10-75.

Pavlík, V.; Bajza, A.; Rousseková, I.; Unčík, S.; Dubík, M. 2007. Degradation of concrete by flue gases from cole combustion, Cement and Concrete Research 37(7): 1085-1095. http://dx.doi.org/10.1016/j.cemconres.2007.04.008

Reinhardt, H. W.; Jooss, M. 2003. Permeability and self-healing of cracked concrete as a function of temperature and crack width, Cement and Concrete Research 33(7): 981-985. http://dx.doi.org/10.1016/S0008-8846(02)01099-2

Robins, P.; Austin, S.; Chandler, J.; Jones, P. 2001. Flexural strain and crack width measurement of steel-fibre-reinforced concrete by optical grid and electrical gauge methods, Cement and Concrete Research 31(5): 719-729. http://dx.doi.org/10.1016/S0008-8846(01)00465-3

Romer, M. 2005. Effect of moisture and concrete composition on the Torrent permeability measurement, Materials and Structures 38(279): 541-547. http://dx.doi.org/10.1617/14321

Stehlík, M.; Adámek, J.; Koukal, J.; Horká I. 2005. Mikrotrhliny a propustnost betonu [Microcracks and permeability of concrete], in The Workshop NDT 2005: Selected papers. $1^{\text {st }}$ ed. Brno: Brno University of Technology, 200-205.

Wang, K.; Jansen, D. C.; Shah, S. P. 1997. Permeability study of cracked concrete, Cement and Concrete Research 27(3): 381-393. http://dx.doi.org/10.1016/S0008-8846(97)00031-8

Wang, T.; Hutchinson, T. C. 2005. Gas leakage rate through reinforced concrete shear walls: numerical study, Nuclear Engineering and Design 235(21): 2246-2260. http://dx.doi.org/10.1016/j.nucengdes.2005.04.006

Yi, S. T.; Hyun, T. Y.; Kim, J. K. 2011. The effect of hydraulic pressure and crack width on water permeability of penetration crack-induced concrete, Construction and Building Materials 25(5): 2576-2583. http://dx.doi.org/10.1016/j.conbuildmat.2010.11.107 
Zhou, Ch.; Li, K.; Pang, X. 2011. Effect of crack density and connectivity on the permeability of microcracked solids, Mechanics of Materials 43(12): 969-978. http://dx.doi.org/10.1016/j.mechmat.2011.08.011

Michal STEHLÍK. PhD, is educated in the field of physical and building material engineering. Nowadays, he works as a Senior Assistant at the Department of Building Testing, Faculty of Civil Engineering, Brno University of Technology. His research interest includes polymer dispersions, treatment of recyclates, durability of concrete, carbonation of concrete, brick masonry.

Věra HEŘMÁNKOVÁ. PhD, is educated in the field of Construction and Transportation Engineering. She works as a Senior Assistant at the Department of Building Testing, Faculty of Civil Engineering, Brno University of Technology. Her research interests include concrete technology, defectoscopy and timber structures.

Lubomír VÍTEK. $\mathrm{PhD}$, is educated in the field of physical and building material engineering. He works as a Research Fellow at the Department of Building Testing, Faculty of Civil Engineering, Brno University of Technology. His research interests include concrete technology, technical radiometry and radiography. 